\section{Lucie Hørlyk, en dansk vestindisk forfatter}

Hundrediret for Danmarks salg af sine sidste kolonier i Vestindien i 1917 nermer sig. I den anledning skriver professor Thomas Riis om den i dag sả godt som ukendte 'koloniforfatter' Lucie Hørlyk (1870-1912). ${ }^{1}$

afprofessor, dr.phil. Thomas Riis, Kiels Universitet

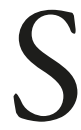
elvom Danmark havde tropiske kolonier i næsten 250 år, opstod der ingen litteratur, der var inspireret af blandingen af europæisk baggrund og livet i kolonierne. Der er ingen danske paralleller til Rudyard Kipling (18651936) eller Henri Bordeaux (18701963), og ingen indfødt vestindisk forfatter synes at have benyttet øernes danske fortid som baggrund for deres fortælling. ${ }^{2}$ To tidligere forfattere benyttede teatret til at tale for slaveriets afskaffelse: Thomas Thaarup med Høstgildet (1790) og H.C. Andersen med Mulatten (1840); men ingen af dem besøgte Vestindien.

Så vidt jeg kan se, er Lucie Hørlyk (1870-1912) en undtagelse. Hun var vokset op i Danmark som datter af en præst, der tilhørte højskolebevægelsen. I 1892 flyttede hun til Vestindien med sin mand, der var blevet udnævnt til politimester og dommer i Frederiksted, St. Croix. Efter hans død i 1903 flyttede hun tilbage til Danmark, hvor hun skrev en række noveller og to romaner med vestindiske emner. ${ }^{3}$ Ved sin død arbejdede hun på endnu en roman, Meta Hauch, som hen-

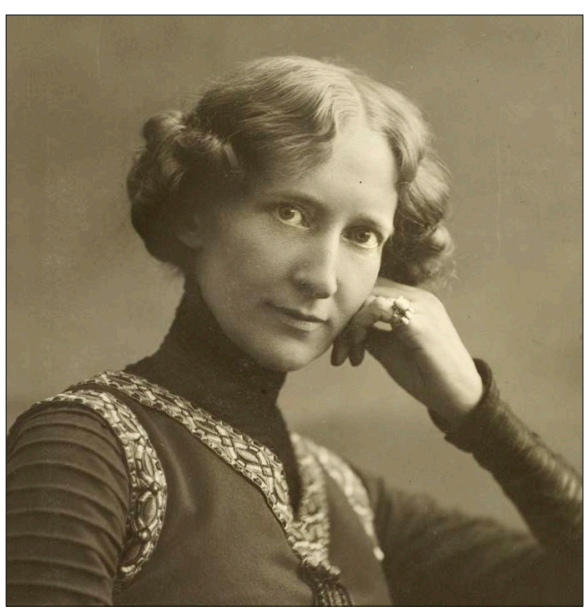

des søster kunne afslutte. Den har intet med Vestindien at gøre og skal derfor ikke beskæftige os her. Blandt Lucie Hørlyks arbejder er også den historiske roman Fra Generalguvernorens Dage (1908), der foregår under Peter von Scholtens styre. Han var generalguvernør i Dansk Vestindien i mange år og afskaffede slaveriet $\mathrm{i}$ 1848 for at undgå blodsudgydelse. Lucie Hørlyk er her bundet af de historiske kendsgerninger, hvilket begrænser hendes muligheder for personlige betragtninger. Af denne grund lønner det sig mere at betragte hendes roman Den gamle Plantage (1909) og hendes noveller, der udkom samlet under fællestitlen Under Tropesol (1907).

Som man kunne vente, spiller forholdet mellem racerne en fremtrædende rolle i disse fortællinger. Et andet foretrukket emne er beskrivelsen af dagliglivet i Vestindien, som hun sammenligner med tilværelsen i det samtidige Europa. I "Nanna Judith", en af novellerne i hendes samling Under Tropesol - Fortallinger fra Dansk Vestindien, udtrykker den nyudnævnte "poor people’s doctor" Jens Bang fra Danmark, som stammer fra en dannet 
familie, sit mishag med den vestindiske livsstil:

“... Den fine portion i byen tiltalte ham ikke. Han syntes, efter de iagttagelser, han hidtil havde gjort, at han i selskab med den snart blev hensat til højsalig Frederik d. VI's dage og snart sprang lidt foran sin egen tid. Etiketten var stram og stivbenet. Standspersonerne vaagede med nidkærhed over den lille stump honneur, der kunne tilkomme hver især. Men samtidig havde den frimodige immoralitet, der herskede i de lavere lag, sneget sig op efter, havde inficeret luften. Han sporede den $\mathrm{i}$ mændenes tale og kvindernes latter. Denne moderniserede Afrika-kynisme passede til den afmaalte bedsteborger-korrekthed som en kokotte i en hestehaars-sofa ...." ${ }^{4}$

I "Nanna Judith" viger dr. Bangs første indtryk efterhånden for en mere nuanceret opfattelse af vestindisk kultur. I løbet af fortællingen tilpasser han sig den vestindiske livsstil og ender med at forlove sig med en kvinde, der er kvadron, dvs. en person, for hvem en af bedsteforældrene var farvet. ${ }^{5}$

I en anden novelle, "Livet 'Derude", står kontrasten mellem vestindisk og dansk livsstil i centrum af fortællingen. Hovedpersonen, Edith, er datter af en dansk dommer, som har giftet sig ind i en planterfamilie. Af hensyn til sin uddannelse blev Edith sendt til Danmark, hvor hun i de seks år, hun der gik i skole, boede hos sin faster og dennes mand, som var professor ved universitetet. Fortællingen begynder aftenen før Ediths hjemkomst til St. Croix, efter at hun har afsluttet skolen. I forventning om hendes ankomst den følgende dag sidder hendes forældre i deres såkaldte "upstairs parlour", hvor man kunne sidde i undertøj eller slåbrok. Ediths fader bliver klar over, hvor grimt rummet egentlig er, og kommer i tanker om dagligstuen i sit barndomshjem. Han husker også, hvad en dansk dame (formentlig hans moder) sagde til ham:

"Vis mig en kvindes opholdsværelse, og jeg skal sige dig, hvem hun er."

Det er navnlig i disse to noveller, "Livet 'Derude"' og "Nanna Judith", at de danske personer ser kritisk på den vestindiske, kreolske ${ }^{7}$ livsstil. For eksempel er dr. Bang ikke begejstret for den fremmedartede vestindiske livsstil, hvor damerne plejede at tilbringe formiddagene i negligé i soveværelset:

"I dette allerhelligste syede man pynt og modtog sine gode bekendte, drak the, spiste frugt, gnaskede sukkergodt og drøftede dagens intimeste nyt. [...] Kom der saa en herrevisit, hvad der hørte til sjældenhederne paa de søgne dage, eller en fjerntstaaende damebekendt, blev der pludselig travl forstyrrelse."

Interessant nok er det ofte de danske mænd, der føler behov for at understrege de sociale konventioner, som kvinderne diskret underminerer. I "Livet 'Derude" er det tydeligt, at mændene først og fremmest vil bevare klasseskellene; men klasse hænger her sammen med spørgsmålet om race. Ediths moder voksede op på en plantage, der blev solgt efter hendes faders død. Alligevel får hun regelmæssigt besøg af dens farvede arbejdere, som fortæller den nyeste sladder fra plantagen. Ediths fader misbilliger sin hustrus og datters hjertelige forhold til farvede kvinder i alle aldre, men opgiver og accepterer deres "choice of acquaintances" for husfredens skyld. ${ }^{9}$

Dog ville det være unfair at betegne Ediths fader som racist. I hans tilfælde er det formentlig først og fremmest et 


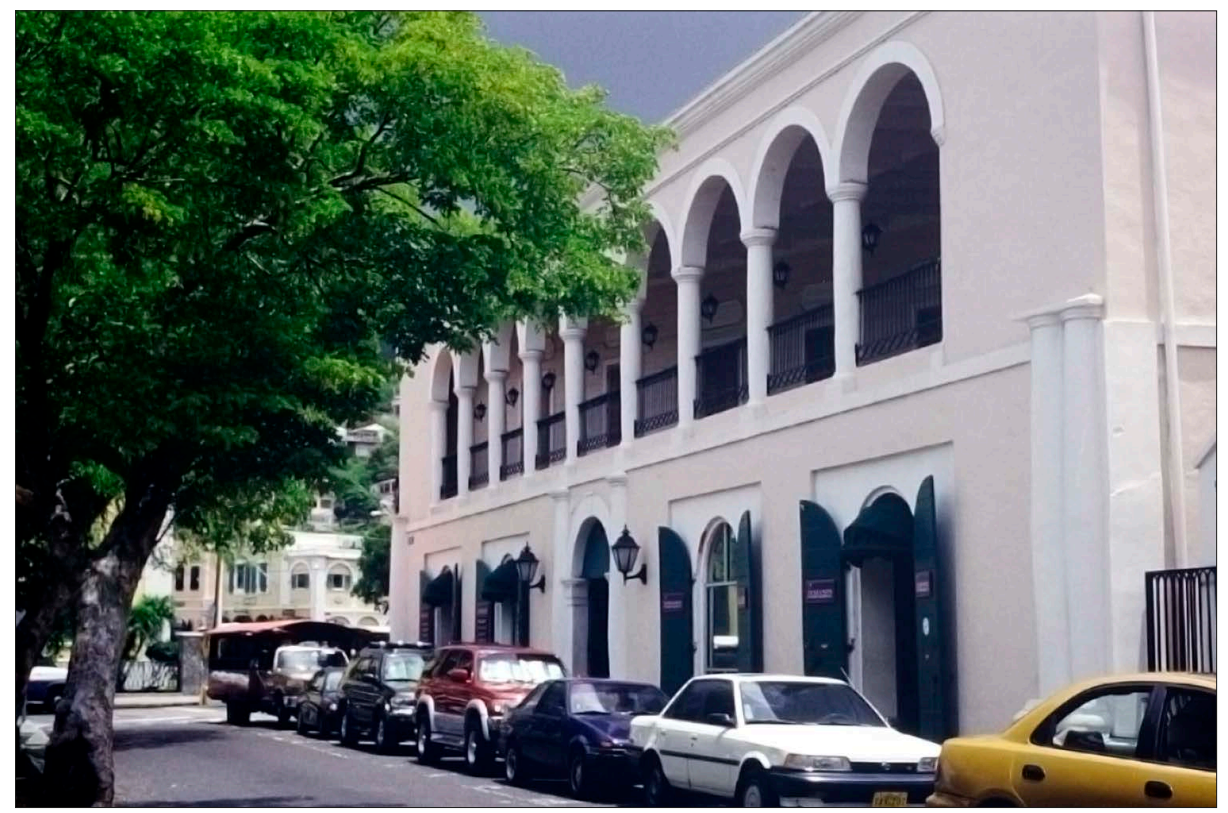

Grand Hotel ved Emancipation Garden, Charlotte Amalie, St. Thomas. Det var på bygningens galleri, at justitsraden i "Nanna Judith" hver aften drak sin rom og vand. Foto ved forf., 2003.

spørgsmål om kulturelt niveau og måske også om kontrasten mellem den moderne intellektuelle kultur i det samtidige Europa og den materialistiske livsstil i kolonierne.

I det daværende Vestindien skulle en ung pige være køn og have en pæn optræden, intet andet betød noget, måske med undtagelse af familiens økonomiske status. ${ }^{10}$ I Ediths person støder de to opfattelser sammen: Hendes fader, tante og dennes mand, der alle var blevet opdraget i den europæiske dannelsestradition, og som kontrast hendes moder, der ganske tydeligt har den materialistiske indstilling.

De to former for livsstil, der er repræsenteret i "Livet 'Derude", er karakteristiske for to klart definerede grupper i det historiske Vestindien: På den ene side de danske embedsmænd, der opfattede sig selv som overklassen; de var de herskende og var langt bedre uddannet, da de kom fra et land med en gammel kultur i modsætning til St. Croix, der først for nylig var blevet koloniseret. Dette gjorde ikke desto mindre intet indtryk på de gamle kreolfamilier, der trak foragteligt på skuldrene af dem. Hvorfor var de taget til St. Croix, havde de ikke haft held med sig hjemme eller havde de kompromitteret sig så meget, at de måtte forsvinde for en tid ? $^{11}$ Dette emne uddyber malerinden Alma Lykke i "Livet 'Derude", da hun for spøg spørger sine gæster, hvad de havde gjort, siden de var blevet nødt til at rejse til Vestindien. ${ }^{12}$

Så vidt jeg kan se, tillader Lucie Hørlyks beskrivelse af kolonisamfundet i Dansk Vestindien os at identificere tre socialgrupper: 


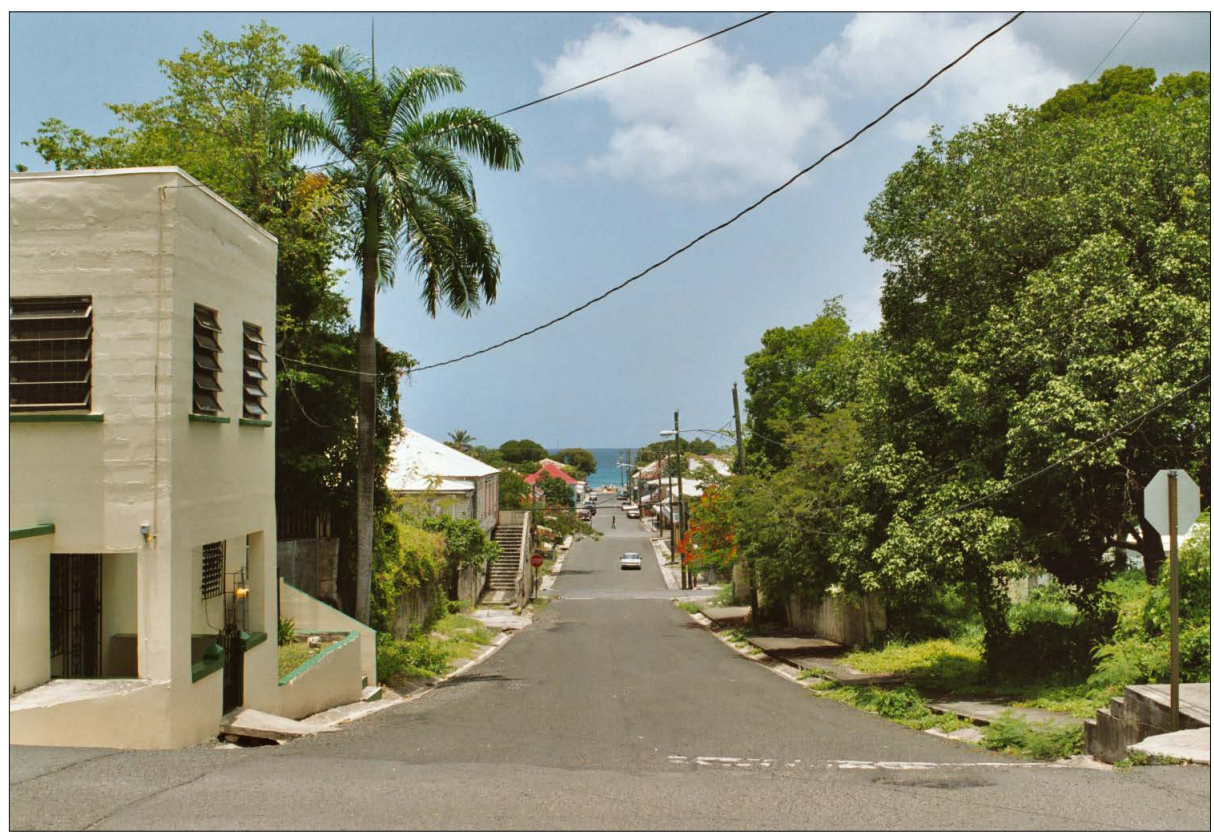

Udsigt over Frederiksted, hvor Lucie Hørlyk boede under sit vestindiske ophold. Foto: Eva Heinzelmann, 2003.

- Embedsmandene med en vis intellektuel dannelse, men i reglen mindre velhavende end

- de gamle kreolfamilier. Kun i sjældne tilfælde stammede disse oprindeligt fra Danmark, og for de fleste var skønhed og rigdom langt vigtigere end intellektuel dannelse. Disse to grupper udgjorde tilsammen overklassen; men ved siden af dem var der et stort

- proletariat, der for flertallets vedkommende var farvet - vi erindrer, at umiddelbart før slaveriets ophævelse var slaverne langt talrigere end de frie. $^{13}$

Vi kan måske nu vove den hypotese, at hvis forfatteren kritiserer proletariatet, er det snarere begrundet i dets manglende dannelse end i dets hudfarve. Vi skal nu betragte hendes opfattelse af forholdet mellem racerne for at se, om denne hypotese er berettiget.

En af samlingens korteste noveller "Hun var hvid" handler om racespørgsmålet. Handlingen er ganske enkel: En hvid familie, der har kendt bedre dage, udlejer stuetagen af familiens hus i Christiansted til en velstående farvet købmand. En dag bliver familiens datter anholdt, da man mistænker hende for at være brudt ind på købmandens lager for at stjæle levnedsmidler. Hun blev ført bort af politiet, hun var smuk som en engel, og pludselig skiftede hoben mening. Havde man til at begynde med været forarget over pigens forbrydelse, kunne alle nu enes om, at

"... det var grusomt, at man kunde behandle hvide folk paa den maade - akkurat som om det var negere! Og naturligvis 
var pigen uskyldig; kan man stjæle, naar man er hvid og smuk som en Guds engel, og desuden: der er da forskel! eller som de udtrykte det; 'der er da folk og folk!'”14

Fortællingen får et vist krydderi, da det viser sig, at hobens anfører ingen anden er end "Queen Mary", som var kendt for sin rolle i optøjerne i $1878,{ }^{15}$ og i dette tilfælde skifter hun lynhurtigt mening. Det er klart, at Lucie Hørlyk her vil vise det farvede proletariats holdning: Man har optaget den kolonialistiske ide, der forbinder hvid hudfarve med dyd, og som nærmere betragtet ser kvindelighed som udtryk for moralsk integritet; til sidst spørger forfatteren ironisk, om en smuk ung kvinde overhovedet kunne gøre sig skyldig $i$ en sådan forbrydelse. Fortællingens slutning blotlægger kolonisamfundets dobbeltmoral.

Spørgsmålet om forholdet mellem racerne bliver i reglen klarest formuleret, når det drejer sig om forholdet mellem mand og kvinde, eller med andre ord, kan en hvid mand gifte sig med en farvet kvinde? Det omvendte forhold - mellem en hvid kvinde og en farvet mand - var i den historiske virkelighed meget sjældent. Mange hvide mænd - enkemænd eller ungkarle - havde farvede husbestyrerinder, med hvem de havde børn, men som aldrig fik en hustrus sociale stilling. Kort tid efter erhvervelsen af St. Thomas afskaffede ironisk nok Danske Lov (1683) en bestemmelse i Jyske Lov fra 1241, som kunne have været meget nyttig i Vestindien: Den fastslog, at havde en mand levet sammen med en kvinde i tre år og hun havde haft en betroet stilling $i$ huset (især at hun havde haft rådighed over nøglerne), ville hun automatisk blive anerkendt som hans retmæssige hustru. ${ }^{16}$ På denne måde ville husholdersken før eller senere kunne blive anerkendt som en retmæssig ægtefælle.

I en af Lucie Hørlyks vestindiske romaner Den gamle Plantage har enkemanden Pablo Gomez en 4-5-årig søn med sin farvede husholderske Silvany; den aften, da Pablos ægtefødte søn kommer hjem, er det hende, der bestemmer måltidet, men hun sidder ikke med ved bordet, da hun ville finde det upassende. Den gamle barnepige forklarer, at Pablo Gomez ikke officielt har anerkendt sin farvede søn, da det ville bringe vanære over hans afdøde hustrus minde og over hans slægt. ${ }^{17}$ I en diskussion med en fransk maler på besøg beskriver Silvany sit forhold til Pablo Gomez således:

"Jeg holder af Mr. Gomez, Sir, som min herre, men ... Han har ingen ord til Silvany, som De, Sir. Hun er kun en farvet og en tjenerinde for ham, Sir;"

- hvortil vi må tilføje, at hun fik et barn med ham. ${ }^{18}$

Mest udførligt bliver forholdet mellem racerne drøftet i novellen "Nanna Judith". Titelpersonen er en farvet kvinde og tidligere slave. Hun havde været husholderske for en skotsk købmand og planter, med hvem hun havde en lyshudet datter, som hed Bell. Hun blev godt opdraget, og hendes tante tilbød at fortsætte hendes opdragelse i Skotland. Efter nogen overvejelse accepterede Nanna Judith tilbuddet, da hun var taknemmelig for, at Bell på denne måde ville blive en dame. ${ }^{19}$ To år senere døde Bells tante, og den unge pige vendte tilbage til St. Thomas. Hendes moder bestemte, at Bell skulle bo med sin fader i familiens hus i Charlotte Amalie, medens hun selv ville blive boende på plantagen. Bells fader anerkendte hende som sit ægtefødte barn, selv om han aldrig giftede sig med hendes moder. Bell æatede en ung englænder, der 


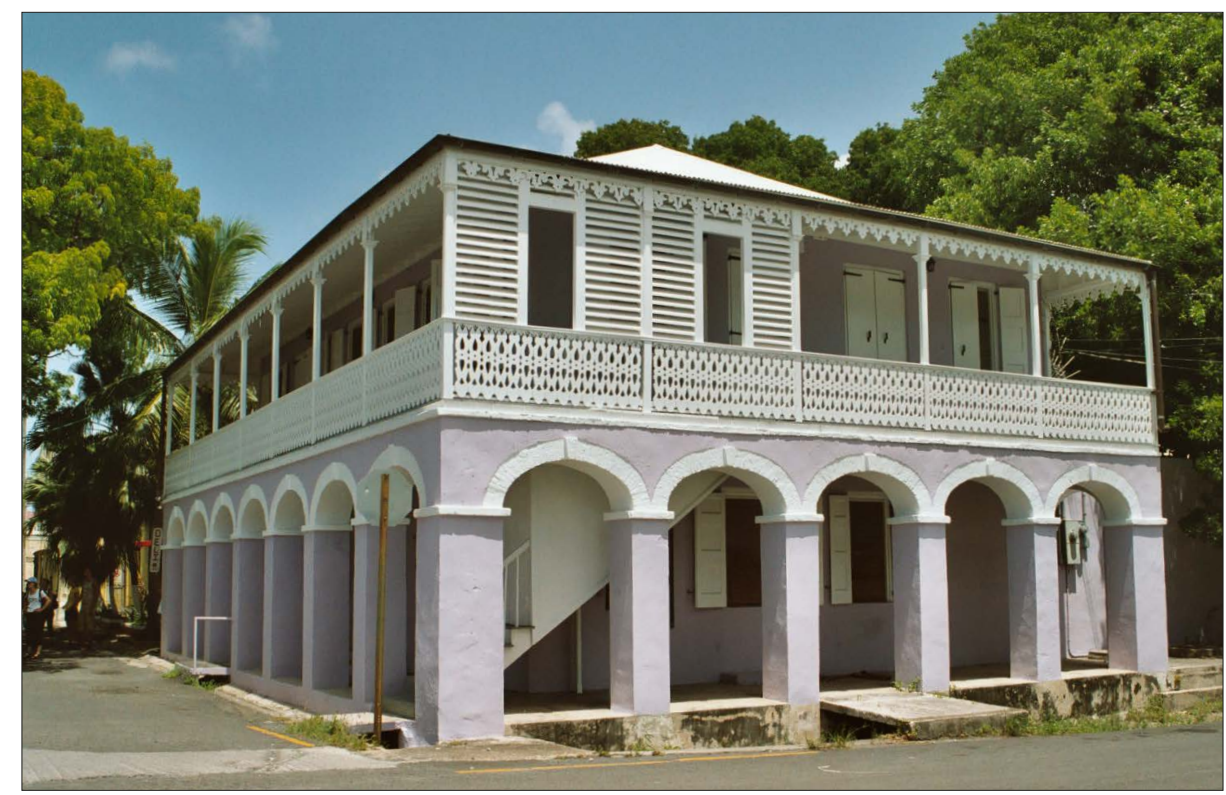

Frederiksted. Typisk vestindisk hus med gallerier på 1. sal. Foto: Eva Heinzelmann, 2003.

i tidens løb overtog sin svigerfaders firma. De havde tre døtre; to var lyshudede som deres moder, den tredie, Marion, var lige så mørk som sin bedstemoder Nanna Judith. Da dr. Bang (som vi allerede har mødt) og Marion forelsker sig i hinanden, venter naboerne ikke uden malice en gentagelse af Nanna Judiths erfaring: "Ingen hvid Massa lader præsten sige amen der!"20 På sit dødsleje genkalder Nanna Judith sig sit liv med Bells fader:

"Det er ikke for sent endnu. Præsterne tror, at de har vundet spillet; en hvid Massa har ingen forpligtelser imod en kulørt pige, siger de. Han gør synd ved at tage hende ind til sig og beholde hende. But ... ingen ting af det er synd, saa længe han ikke hører efter præsterne."21

Kort før hendes død fortæller dr. Bang hende, at han vil gifte sig med Marion; Nanna Judith kan nu dø med fred i sjælen, hendes anstrengelser for at få Bell og hendes døtre socialt accepterede var ikke forgæves.

I dette tilfælde gifter en hvid mand sig med en farvet kvinde, og også i romanen Den gamle Plantage gifter Pablo Gomez' søn sig med Benedicte, der er datter af en dansk planter og en farvet kvinde. Sandsynligvis repræsenterer Benedictes fader fremtiden, han er flittig og energisk, netop den type person, man havde brug for, for at føre de højst nødvendige reformer ud i livet. ${ }^{22}$ Fortællingens lykkelige udgang viser, hvor unfair det ville være at betegne Lucie Hørlyk som racist.

Hvad vi i dag ville betegne som racistisk, blev ikke nødvendigvis betragtet således i det 19. århundrede, da eliterne gik ud fra europæernes kulturelle og racemæssige overlegenhed som en selvfølge. Tværtimod, Lucie Hørlyk finder det 
naturligt, at farvede og hvide på samme sociale niveau gifter sig med hinanden. Her viser hendes opfattelse af blandede xgteskaber inden for den samme sociale klasse sig som fremskridtsvenlig. Man kan ganske vist kritisere hendes negative opfattelse af det (hovedsagelig farvede) proletariat, men igen her er det et spørgsmål om opførsel snarere end om hudfarve.

I Lucie Hørlyks fortællinger skinner hendes personlige opfattelse af det

\section{Noter}

1 En tidligere, engelsk version af artiklen blev holdt som foredrag ved University of the Virgin Islands 2003 og ved konferencen America Seawise: North American Islands in the Atlantic i Kiel 2010.

2 Om det danske kolonistyre i Vestindien, se f.eks. Eva Heinzelmann, Stefanie Robl \& Thomas Riis (udg.): Der dänische Gesamtstaat. Ein unterschätztes Weltreich? I The Oldenburg Monarchy: An Underestimated Empire? Kiel 2006, især s. 37-49, 257-269, 317-326 og Christian Degn:

Die Schimmelmanns im atlantischen Dreieckshandel: Gewinn und Gewissen. 3. udg. Neumünster 2000, især s. 32-42.

3 Susanne Fabricius: "Lucie Hørlyk", Dansk Biografisk Leksikon, 3. udg., VII, 1981, s. 57-58.

4 "Nanna Judith", s. 11.

5 "Nanna Judith", s. 56.

6 "Livet 'Derude", s. 65.

7 Kreolsk betegner efterkommere af europæere, der er vokset op i Vestindien.

8 "Nanna Judith", s. 39.

9 "Livet 'Derude", s. 67.

10 "Livet 'Derude", s. 123.

11 Den gamle Plantage, s. 13-14.

12 "Livet 'Derude", s. 104-106.

13 Jens Vibæk: Dansk Vestindien 1755-1848. I: Vore gamle Tropekolonier. 2. udg., II, 1966.

14 "Hun var Hvid", s. 218. vestindiske samfund igennem. Selv om hun undertiden udtrykker kritik, ville det være forkert at opfatte hende som racist, tværtimod er hun for racemæssigt blandede ægteskaber.

Der er bevaret dagbøger og erindringsværker fra Dansk Vestindien, men Lucie Hørlyk er den eneste, der har givet sine indtryk litterært udtryk. Af denne grund fortjener hun en særlig plads i dansk litteratur.

15 I 1878 havde der på St. Croix været et voldeligt oprør blandt øens farvede arbejdere, der kom fra hele Vestindien. Under det såkaldte oktoberoprør kæmpede folk imod, at de blev udbyttet af de hvide plantageejere i Vestindien. "Queen Mary" er bekendt som en af den farvede befolknings "besværligste" oprørere. Christian Degn: Die Schimmelmanns im atlantischen Dreieckshandel: Gewinn und Gewissen, s. 509-512, 570 . I dag er en boulevard på St. Croix opkaldt efter hende. Se videre om den historiske baggrund for oprøret i Palle Lauring: Dansk Vestindien. Historien og øerne, 1978, s. 179-184.

16 Jyske Lov, Text 1. I: Peter Skautrup (udg.): Danmarks gamle Landskabslove, II, 1933, s. 68-69 (Bog I \$ 27).

17 Den gamle Plantage, s. 104-107.

18 Den gamle Plantage, s. 159.

19 "Nanna Judith", s. 22-23.

20 "Nanna Judith", s. 48.

21 "Nanna Judith", s. 50. Hvis den af Lucie Hørlyk beskrevne indstilling svarer til virkeligheden, forstår man, hvorfor raceintegration er en meget langsom proces.

22 Det danske parlaments forkastelse af salgstraktaten i 1902 førte til udarbejdelsen af et omfattende reformprogram (1903), der kun til dels var blevet realiseret, da øerne blev solgt til USA i 1917. 


\section{Litteratur}

Christian Degn: Die Schimmelmanns im atlantischen Dreieckshandel: Gewinn und Gewissen. Neumünster 1974.3. udg. 2000.

Susanne Fabricius: "Lucie Hørlyk" I: Sv. Cedergreen Bech (red.): Dansk Biografisk Leksikon, 3. udg., VII, 1981, s. 57-58.

Eva Heinzelmann, Stefanie Robl \& Thomas Riis (udg.): Der dänische Gesamtstaat. Ein unterschätztes Weltreich? / The Oldenburg Monarchy: An Underestimated Empire? Kiel 2006. Lucie Hørlyk: Under Tropesol. Fortallinger fra Dansk Vestindien. 1907. 2. udg. 1913. Delvis oversat til engelsk 1969.

Lucie Hørlyk: Fra Generalguvernørens Dage. Fortelling fra Dansk Vestindien. 1908. 2. udg. 1912.

Lucie Hørlyk: Den gamle Plantage. Fortelling fra Dansk Vestindien. 1909. 3. opl. 1913. Tysk oversættelse 1911. Jyske Lov, Text 1. (Bog I § 27). I: Peter Skautrup (udg.): Danmarks gamle Landskabslove II, 1933, s. 68-69.

Palle Lauring: Dansk Vestindien. Historien og øerne. 1978.

Jens Vibæk: Dansk Vestindien 1755-1848. I: Vore gamle Tropekolonier. 2. udg., II, 1966.

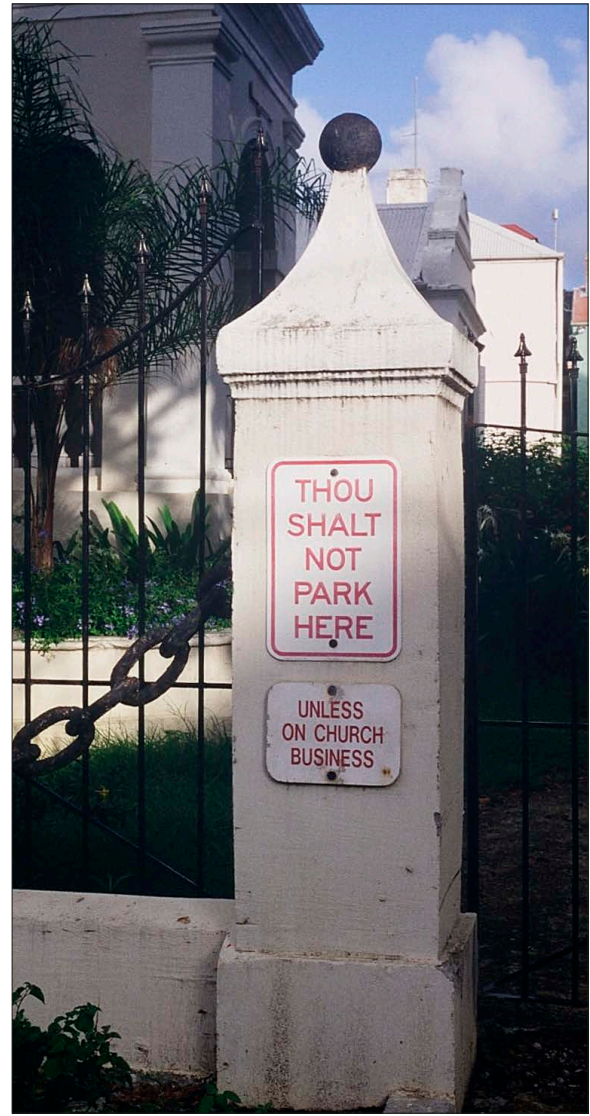

Indgangen til den lutherske kirke $i$ Christiansted. Foto ved forfatteren, 2003. 